\title{
Serum lutein concentrations in healthy term infants fed human milk or infant formula with lutein
}

\author{
Jodi Bettler $\cdot$ J. Paul Zimmer $\cdot$ Martha Neuringer . \\ Patricia A. DeRusso
}

Received: 3 April 2009/Accepted: 29 July 2009/Published online: 12 August 2009

(C) The Author(s) 2009. This article is published with open access at Springerlink.com

\begin{abstract}
Background Lutein is a carotenoid that may play a role in eye health. Human milk typically contains higher concentrations of lutein than infant formula. Preliminary data suggest there are differences in serum lutein concentrations between breastfed and formula-fed infants.

Aim of the study To measure the serum lutein concentrations among infants fed human milk or formulas with and without added lutein.

Methods A prospective, double-masked trial was conducted in healthy term formula-fed infants $(n=26)$ randomized between 9 and 16 days of age to study formulas containing 20 (unfortified), 45, 120, and $225 \mathrm{mcg} / \mathrm{l}$ of lutein. A breastfed reference group was studied $(n=14)$ and milk samples were collected from their mothers. Primary outcome was serum lutein concentration at week 12 . Results Geometric mean lutein concentration of human milk was $21.1 \mathrm{mcg} / \mathrm{l}$ (95\% CI 14.9-30.0). At week 12, the human milk group had a sixfold higher geometric mean
\end{abstract}

J. Bettler · J. P. Zimmer · P. A. DeRusso

Wyeth, Collegeville, PA, USA

\section{Neuringer}

Oregon National Primate Research Center,

Section of Clinical Nutrition and Department of Ophthalmology,

Oregon Health and Science University,

Portland, OR 97239, USA

Present Address:

J. P. Zimmer

Martek Biosciences Corporation, 4909 Nautilus Ct N,

Suite 208, Boulder, CO 80301, USA

P. A. DeRusso ( $\square)$

Wyeth Pharmaceuticals, 200 Campus Drive,

Collegeville, PA 19426, USA

e-mail: derussp@wyeth.com serum lutein $(69.3 \mathrm{mcg} / \mathrm{l} ; 95 \%$ CI $40.3-119)$ than the unfortified formula group (11.3 mcg/l; 95\% CI 8.1-15.8). Mean serum lutein increased from baseline in each formula group except the unfortified group. Linear regression equation indicated breastfed infants had a greater increase in serum lutein (slope $3.7 ; P<0.001$ ) per unit increase in milk lutein than formula-fed infants (slope $0.9 ; P<0.001$ ). Conclusions Breastfed infants have higher mean serum lutein concentrations than infants who consume formula unfortified with lutein. These data suggest approximately 4 times more lutein is needed in infant formula than in human milk to achieve similar serum lutein concentrations among breastfed and formula fed infants.

Keywords Lutein - Human milk - Infant formula . Serum $\cdot$ Bioavailability

\section{Introduction}

Lutein is a carotenoid that selectively accumulates in the macular region of the retina and protects retinal cells required for vision [16]. Humans cannot synthesize lutein and thus all lutein in the human body comes from dietary sources. Studies in adults have revealed that dietary or supplemental lutein leads to variable increase both in serum lutein and in macular pigment $[8,13]$. Some epidemiological evidence suggests lutein may reduce the risk of age-related macular degeneration [22, 24].

Lutein may be important well before adulthood. Lutein is present in cord blood at the time of newborn delivery indicating placental transfer to the fetus, and cord blood concentrations are highly correlated to maternal serum concentrations [28]. Lutein is present in human donor eyes as early as 17-22 weeks gestation [1,9]. After birth, 
breastfed infants receive lutein from mother's milk [2]. At 1 month of age there are differences in serum lutein concentrations between breastfed and formula-fed infants [14]. This finding is plausible because there are higher concentrations of lutein in human milk than in infant formulas. Infant formulas contain a small amount of innate lutein contributed by ingredients in the formula.

A next step in understanding lutein nutrition in early life is to determine serum lutein concentrations of exclusively breastfed and formula-fed infants. The aim of this study was to examine serum lutein concentrations in infants fed human milk or formulas unfortified and fortified with lutein. This study is unique because it is the first prospective study of serum lutein concentrations in healthy fullterm infants consuming different concentrations of lutein in formula in comparison to serum lutein concentrations in human milk fed infants.

\section{Methods}

\section{Subjects}

This $3 \frac{1}{2}$ month double-masked, parallel, prospective 12 week feeding study enrolled exclusively formula-fed and breastfed infants. Infants were recruited from hospitals and pediatric practices in the Portland, Oregon area. Oregon Health and Science University Institutional Review Board approved the study protocol and the informed consent form. Infant inclusion criteria included: healthy singleton term infants (37-42 weeks gestation) between 9 and 16 days of age, parent or guardian of formula-fed infants agreed to feed assigned study formula ad libitum, and breastfeeding mother's agreed to exclusively breastfeed for duration of study. An inclusion criterion for a breastfeeding mother was a self-reported consumption of 6 or more $1 / 2$-cup servings per week of dark green vegetables, which are a rich source of lutein [11]. To verify consumption, each breastfeeding mother at study entry completed a validated, semi-quantitative food frequency questionnaire [4]. Questionnaires were analyzed at the Harvard School of Public Health and lutein intake was calculated from the Harvard University food composition database derived from the USDA Survey Nutrient database plus other sources.

\section{Study formulas}

The lutein fortification concentrations targeted for this study were 25,100 , and $200 \mathrm{mcg}$ lutein per liter of formula. These concentrations were chosen because they are within the range of lutein concentrations observed in the largest, multinational study of breast milk carotenoids [2]. Study formulas were analyzed several times during the trial to monitor actual lutein content in the formulas over time. Lutein was present in the raw material and the innate amount of lutein was $\sim 20 \mathrm{mcg} / \mathrm{l}$, which contributed to the final lutein concentration in the formula. Thus, the four study formulas contained the following average concentrations of lutein as confirmed by analysis: 20 (unfortified), 45,120 , and $225 \mathrm{mcg} / \mathrm{l}$. At enrollment, formula-fed infants were randomized to one of these four study formulas, all of which were based on Wyeth S-26 Gold (Askeaton, Ireland). The source of lutein for the fortified formulas was FloraGLO $^{\circledR}$ lutein $20 \%$ liquid in safflower oil (Kemin Industries, Inc., Des Moines, Iowa). The lutein in this material was supplied as purified oleoresin obtained from the extraction, purification, and crystallization of oleoresin from the marigold flower. A saponification step in the processing created free lutein from lutein esters. Study formulas were supplied as ready-to-feed liquid in $250 \mathrm{ml}$ tetrabriks with (per 1): $14.3 \mathrm{~g}$ protein, $73 \mathrm{~g}$ carbohydrate, $36 \mathrm{~g}$ fat, and 672 calories. All formulas contained approximately $135 \mathrm{mcg} / \mathrm{l}$ of beta-carotene, and other micronutrients did not differ among the formulas.

\section{Human milk and serum samples}

Human milk was collected using an Avent ISIS $^{\mathrm{TM}}$ breast pump (Philips Avent, London, UK) [5] at mid-afternoon from each breastfeeding mother the day before study visit weeks 4, 8, and 12. A single, mid-afternoon sample of breast milk represents the average 24-h concentration of lutein [6]. The mother expressed the sample into clean bottles and stored it in the home freezer until the study visit the following day.

Serum lutein concentrations were determined from infant blood samples collected at baseline and week 12 . Whole blood (1-2 ml) was obtained from each infant by venipuncture by a registered pediatric phlebotomist or by heel stick by a pediatric registered nurse.

Human milk and serum samples were stored at $-80{ }^{\circ} \mathrm{C}$ at the study site in a cryobox for light sensitive specimens, shipped on dry ice to a contract bioanalytical laboratory (Craft Technologies, Inc., Wilson, North Carolina), and verified frozen on arrival. Samples were stored at $-70{ }^{\circ} \mathrm{C}$ before being analyzed. All laboratory lights were covered with ultraviolet filters to protect samples from degradation. Human milk was analyzed for milk lipid concentration determined by creamatocrit [17] and carotenoid composition.

Lutein and beta-carotene analyses

Serum concentrations of lutein and beta-carotene were measured by Craft Technologies using high performance liquid chromatography (HPLC) with multiwavelength photodiode-array absorbance detection as previously 
described [19]. A $150 \mu \mathrm{l}$ volume of serum was mixed with an equal volume of buffer and then mixed with two volumes of ethanol containing the internal standard (tocol). Lutein and beta-carotene were extracted from the aqueous phase into hexane. The combined hexane extracts were dried under vacuum. The extract was redissolved in ethyl acetate and diluted in mobile phase. An aliquot was injected onto a $\mathrm{C} 18$ reversed phase column and eluted isocratically. The analytes possess absorbance that is proportional to their concentration in solution and therefore these properties were used for quantitative analysis. Lutein and beta-carotene were measured by absorbance at $450 \mathrm{~nm}$. Chromatograms were recorded using a computer data system. Analytes were quantified by external standard quantitation using neat standards to calculate response factors based on the peak area of the analyte. The quantities of analytes were corrected for recovery post-run based on the internal standard. Coefficient of variation was less than $7 \%$.

Concentrations of these analytes in human milk were determined after saponification of the samples. An aliquot of milk sample was mixed with potassium hydroxide in methanol (with pyrogallol added as antioxidant) and allowed to stand overnight in a refrigerator to hydrolyze lipids. Each sample was then extracted by use of tetrahydrofuran and hexane; the combined extracts of each sample were evaporated under vacuum and the residue was dissolved and analyzed by reversed-phase HPLC as described above.

\section{Statistical methods}

Human milk and serum lutein concentrations were not normally distributed and data are presented as geometric means and 95\% two-sided confidence intervals. Linear regression was performed to analyze the relationship between lutein in the milks and lutein in serum at week 12 . Linear regression analyses were performed with and without baseline serum lutein concentrations in the model. Final regression lines do not include baseline serum lutein concentrations as a covariate.

\section{Results}

The mean (SD) age at study entry was $13( \pm 2.0)$ days. A total of 40 infants were enrolled, including 14 human milkfed and 26 formula-fed infants (Table 1). Eighty-five percent (34/40) of enrolled infants completed the study. Six infants did not complete the study due to the following reasons: 2 infants were lost to follow-up; 2 families moved out of the area; 1 infant was no longer exclusively human milk-fed, and 1 formula-fed infant withdrew due to an adverse event that was not related to the formula according to the study pediatrician.

Lutein concentrations in human milk and lutein in the diet of breastfeeding mothers

Geometric mean lutein concentrations in human milk samples were similar at weeks 4,8 , and 12 (Table 2). The mean lipid content of the human milk samples was $41.5 \mathrm{~g} / \mathrm{l}$ (95\% CI 37.4-46.0). The average lutein concentration from the three collections of all breastfeeding mothers was $21.1 \mathrm{mcg} / \mathrm{l}(95 \%$ CI 14.9-30.0) and the average amount of lutein per gram of milk fat was $0.492 \mathrm{mcg}$ (95\% CI 0.319 0.761). Analysis of the Food Frequency Questionnaire,
Table 1 Infant demographic information at enrollment

\begin{tabular}{|c|c|c|c|c|c|}
\hline & \multicolumn{4}{|c|}{$\begin{array}{l}\text { Randomized formula-fed group } \\
\text { Formula lutein concentration (mcg/l) }\end{array}$} & \multirow{2}{*}{$\begin{array}{l}\text { Breastfed group } \\
\text { Human milk } \\
(n=14)\end{array}$} \\
\hline & $\begin{array}{l}20[\text { Control }] \\
(n=6)\end{array}$ & $\begin{array}{l}45 \\
(n=6)\end{array}$ & $\begin{array}{l}120 \\
(n=7)\end{array}$ & $\begin{array}{l}225 \\
(n=7)\end{array}$ & \\
\hline \multicolumn{6}{|l|}{ Age at enrollment (days) } \\
\hline Mean $\pm \mathrm{SD}$ & $13 \pm 1.3$ & $12 \pm 2.7$ & $13 \pm 2.1$ & $14 \pm 1.1$ & $13 \pm 2.1$ \\
\hline Median & 13 & 12 & 14 & 14 & 13 \\
\hline Range & $11-15$ & $9-15$ & $10-16$ & $12-15$ & $9-15$ \\
\hline Female sex $[n(\%)]$ & $4(67)$ & $3(50)$ & $5(71)$ & $5(71)$ & $7(50)$ \\
\hline \multicolumn{6}{|l|}{ Race $[n(\%)]$} \\
\hline White & $5(83)$ & $5(83)$ & $6(86)$ & $4(57)$ & $12(86)$ \\
\hline Black & $1(17)$ & $0(0)$ & $0(0)$ & $0(0)$ & $0(0)$ \\
\hline Other & $0(0)$ & $1(17)$ & $1(14)$ & $3(43)$ & $2(14)$ \\
\hline \multicolumn{6}{|l|}{ Anthropometrics } \\
\hline Weight (kg) & $3.8 \pm 0.4$ & $3.9 \pm 0.6$ & $3.3 \pm 0.4$ & $3.9 \pm 0.4$ & $3.8 \pm 0.4$ \\
\hline Length (cm) & $51.1 \pm 1.5$ & $52.5 \pm 3.4$ & $50.1 \pm 2.8$ & $51.4 \pm 1.1$ & $51.8 \pm 2.2$ \\
\hline Head circumference $(\mathrm{cm})$ & $35.9 \pm 1.2$ & $36.1 \pm 0.8$ & $34.7 \pm 1.2$ & $36.2 \pm 1.3$ & $36.1 \pm 1.2$ \\
\hline
\end{tabular}


Table 2 Lutein concentrations in human milk at different study times

\begin{tabular}{lllll}
\hline & $\begin{array}{l}\text { Week } 4 \\
n=13\end{array}$ & $\begin{array}{l}\text { Week } 8 \\
n=13\end{array}$ & $\begin{array}{l}\text { Week 12 } \\
n=12\end{array}$ & $\begin{array}{l}\text { Average } \\
n=13\end{array}$ \\
\hline $\begin{array}{l}\text { Lutein (mcg/l) } \\
\text { Geometric mean }\end{array}$ & 20.5 & 20.1 & 19.7 & 21.1 \\
$95 \%$ CI & $12.8-32.9$ & $15.5-26.1$ & $12.3-31.5$ & $14.9-30.0$ \\
Median & 21 & 20 & 21.5 & 23 \\
Range & $6-61$ & $9-37$ & $3-50$ & $7-48$ \\
\hline
\end{tabular}

Limit of detection of lutein in human milk was $0.4 \mathrm{mcg} / \mathrm{l}$

which was designed to report dietary intakes of both lutein and its structural isomer, zeaxanthin, indicated that the median lutein plus zeaxanthin in the maternal diet was $3363 \mathrm{mg} /$ day [mean $4286 \mathrm{mg} /$ day (95\% CI 2679-5892)].

Lutein concentrations in infant serum

Human milk-fed infants had higher mean serum lutein concentrations $(81 \mathrm{mcg} / \mathrm{l})$ than all formula-fed infants $(13 \mathrm{mcg} / \mathrm{l})$ at baseline. Serum lutein concentration increased from baseline in each of the formula groups except in the unfortified group (Table 3). Linear regression model with and without baseline serum lutein indicated baseline serum concentrations did not have a significant effect on final serum concentrations in either the formula $(P<0.001)$ or human milk fed groups $(P=0.001)$. After 12 weeks of feeding, the human milk group had a sixfold higher mean serum lutein concentration than the unfortified formula group. Fortification of formula with lutein resulted in a dose-dependent increase in serum lutein concentrations after 12 weeks.
Relationship between dietary lutein and infant serum lutein concentrations

A positive linear dose-dependent relationship (Fig. 1) was observed between lutein in the formula and lutein in the serum. The slope of the regression equation was steeper for human milk lutein than lutein in formula. For infants fed human milk, serum lutein concentration increased approximately $3.7 \mathrm{mcg} / \mathrm{l}$ for every $1 \mathrm{mcg} / \mathrm{l}$ increase in human milk lutein concentration, whereas for infants fed formula, serum lutein concentration increased only $0.9 \mathrm{mcg} / \mathrm{l}$ for every $1 \mathrm{mcg} / \mathrm{l}$ increase in formula lutein concentration.

Lutein fortification and serum beta-carotene concentrations

The mean average serum beta-carotene concentration at baseline across all formula-fed groups was $24.4 \mathrm{mcg} / \mathrm{l}$. In the infants fed the 20 (control), 45, 120, and $225 \mathrm{mcg} / \mathrm{l}$ lutein containing formulas, the corresponding serum betacarotene concentrations at week 12 were 128.0 (95\% CI 47.3-346.6), 201.2 (95\% CI 98.4-411.2), 173.2 (95\% CI 125.5-238.8), and $202.3 \mathrm{mcg} / \mathrm{l}$ (95\% CI 139.5-293.3), respectively.

\section{Safety evaluation}

Infant growth was within normal limits as assessed by mean weight gain in grams per day as well as by means for Z-scores in weight, length, and head circumference (data not shown). There were no adverse events related to the formula and no serious adverse events reported.
Table 3 Lutein concentrations in infant serum at study entry and week 12

Limit of detection of lutein in the serum was $2 \mathrm{mcg} / \mathrm{l}$

\begin{tabular}{|c|c|c|c|c|c|}
\hline & \multicolumn{4}{|c|}{$\begin{array}{l}\text { Randomized formula-fed group } \\
\text { Formula lutein concentration (mcg/l) }\end{array}$} & \multirow{2}{*}{$\begin{array}{l}\text { Breastfed group } \\
\text { Human milk }\end{array}$} \\
\hline & 20 [Control] & 45 & 120 & 225 & \\
\hline \multicolumn{6}{|l|}{ Study entry } \\
\hline$n$ & 6 & 6 & 7 & 7 & 14 \\
\hline Geometric mean & 11.9 & 12.9 & 22.4 & 8.5 & 81 \\
\hline $95 \% \mathrm{CI}$ & $6-23.9$ & $6.9-24$ & $11.2-45$ & $6.3-11.6$ & $51-128.6$ \\
\hline Median & 10 & 13.5 & 26 & 8 & 95 \\
\hline Range & $7-40$ & $5-25$ & $8-46$ & $6-17$ & $19-236$ \\
\hline \multicolumn{6}{|l|}{ Week 12} \\
\hline$n$ & 4 & 5 & 7 & 5 & 13 \\
\hline Geometric mean & 11.3 & 35.9 & 107.5 & 192.1 & 69.3 \\
\hline $95 \% \mathrm{CI}$ & $8.1-15.8$ & $30.1-42.8$ & 88-131.4 & $141.7-260.6$ & $40.3-119$ \\
\hline Median & 11.5 & 37 & 109 & 180 & 66 \\
\hline Range & $9-14$ & $31-42$ & $82-148$ & $148-278$ & $7-168$ \\
\hline
\end{tabular}




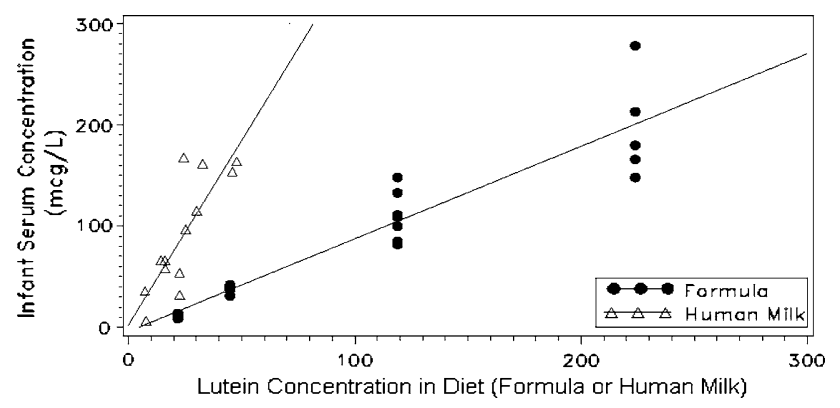

Fig. 1 Scatterplot of serum lutein concentrations $(\mathrm{mcg} / \mathrm{l})$ at week 12 in infants fed different concentrations $(\mathrm{mcg} / \mathrm{l})$ of lutein containing formula or human milk. Solid circles represent infant formula groups and open triangles represent human milk group. Linear regression equation for formula-fed groups was $\mathrm{Yi}=-4.4+0.9$ (formula lutein) $\left(r^{2}=0.87, P<0.001\right)$ and for the human milk group was $\mathrm{Yi}=1.8+3.7$ (human milk lutein) $\left(r^{2}=0.67, P<0.001\right)$. Baseline serum concentrations did not have a significant effect on final serum concentrations $(P=0.001$ for human milk; $P<0.001$ for formula) and the slopes shown are based on unadjusted data

\section{Discussion}

This is the first randomized, prospective study comparing serum lutein concentrations in healthy term infants consuming different concentrations of lutein in formula. An important finding from this study is that the breastfed infant reference group had approximately 6 times the mean serum lutein concentration of infants consuming unfortified formula during the first several months of life. Fortification of formula with lutein resulted in a dose-dependent increase in serum lutein. Approximately 4 times more lutein is needed in the formula than in human milk to achieve similar serum lutein concentrations among the breastfed and formula fed infants.

It is interesting to note that despite the similarity in the lutein concentration of human milk and the unfortified formula, serum lutein concentrations were markedly different in the two groups of infants at week 12 but also at study entry. Two observations may account for this finding. Although we did not measure cord blood lutein concentrations, cord blood lutein did not differ at birth among infants who were ultimately fed human milk or infant formula (unpublished data, Wyeth, Dr. Minervini, 1993). However, infants who receive breast milk immediately after birth most likely consume substantially more lutein from colostrum than infants who consume infant formula unfortified with lutein $[23,25]$ and would explain the differences in serum lutein at study entry. In our study, the mothers reported at study enrollment that approximately $86 \%$ of the infants in the human milk group were exclusively breastfed from birth and $77 \%$ of the infants in the formula fed group received exclusively commercial formula.

Secondly, our data suggest that the bioavailability of lutein from formula is considerably lower than from human milk and could explain the lower mean serum lutein concentration in the unfortified group at week 12 despite similar lutein concentrations in the human milk and unfortified formula. The ratio of the slopes from the linear regression lines indicates that a fourfold higher lutein concentration was needed in formula compared to human milk to achieve similar lutein concentrations between formula-fed and breastfed infants. The reason why lutein availability was different between human milk and luteinfortified formula remains unclear. Lutein added to the formula is predominantly free lutein and similar to the dominant form of lutein in human milk. Several findings reveal that availability of lutein from foods would be affected by several factors including the food matrix, fat intake, and nutrient-nutrient interactions $[3,7,10,20,21$, 27]. In relation to those points, additional studies are needed to explain the difference in bioavailability.

The human milk lutein concentration in this study was similar to the average values in the largest human milk survey published to date [2] reporting human milk lutein data from lactating women in nine countries including the US. Because dietary carotenoid intake influences human milk lutein concentrations, a goal of our study was to enroll breastfeeding mothers who consumed a diet rich in lutein. A study inclusion criterion for breastfeeding mothers was a reported consumption of 6 or more $1 / 2$-cup servings per week of dark green vegetables, which are a rich source of lutein [11]. The results of the Food Frequency Questionnaire indicated that our goal of recruiting a population of breastfeeding women with a rich dietary intake of lutein was achieved. When compared to a sample of women from the Women's Health Initiative, the breastfeeding mothers in our study fell between the 60th and 80th percentiles of intakes observed in the much larger study $(n=1698)$ [18].

There is limited information regarding lutein concentrations in infant formulas. Lutein is currently not added to infant formulas in the US but it has been detected in the ingredients used in infant formula manufacturing. Unpublished data from our laboratory indicate typical skim milk powder and whey protein ingredients contain lutein in amounts from $<3.3$ to $10.2 \mathrm{mcg} / 100 \mathrm{~g}$ and $<3.3$ to $15.6 \mathrm{mcg} / 100 \mathrm{~g}$, respectively. One study [12] reported lutein in formulas and in human milk samples from Northern Ireland mothers and found that most formulas studied had detectable lutein and the range of concentrations in formula was similar to the range of concentrations found in human milk.

Serum beta-carotene concentrations were measured in this study because interactions between lutein and betacarotene have been reported. Competition between lutein and beta-carotene for absorption was observed in healthy adults consuming supplements [15] and vegetable sources [26]. Lutein reduced beta-carotene concentrations in some 
subjects and enhanced it in others [15]. In our study, all infants were given formula with the same concentration of beta-carotene but the infants who consumed lutein supplemented formula had higher mean serum beta-carotene concentrations than infants who consumed control formula. These data suggest lutein supplementation enhanced absorption of beta-carotene but additional studies are needed to confirm.

The strengths of this study include the use of a wide range of lutein concentrations in the formula, measurement of lutein concentrations in the human milk, and the length of time exclusively formula or breastfed. The small sample size for each group could be considered a limitation of the study although a linear dose response relationship was apparent. The exclusion criteria of infants less than 9 days old limits our understanding of the amount of lutein in colostrum and how it might have had an early impact on baseline serum lutein concentrations. However, requiring that the infants be older than a week at study entry was necessary to avoid recruiting into a trial during a time when a mother might be deciding between breast and formula feeding.

In summary, infants fed formula unfortified with lutein have serum lutein concentrations approximately one-sixth those of breastfed infants in the first few months of life. An increase in lutein in infant formula leads to an increase in serum lutein in a dose-dependent manner. More lutein is needed in infant formula than human milk to achieve similar serum lutein concentrations among breastfed and formula fed infants. Additional studies are needed to demonstrate whether lutein fortification in infant formula leads to improved eye health or other benefits.

Acknowledgments We are grateful to Kristina Krabill, the study nurse and coordinator; Dr. Pam Fisher who was the study pediatrician and performed the physical examinations; Dr. Jay Groebel for his statistical assistance; and Susan Troemel for her help with this study. The study was supported by Wyeth Nutrition, Collegeville, PA, USA.

Open Access This article is distributed under the terms of the Creative Commons Attribution Noncommercial License which permits any noncommercial use, distribution, and reproduction in any medium, provided the original author(s) and source are credited.

\section{References}

1. Bone RA, Landrum JT, Fernandez L, Tarsis SL (1988) Analysis of the macular pigment by HPLC: retinal distribution and age study. Invest Ophthalmol Vis Sci 29:843-849

2. Canfield L, Clandinin M, Davies D, Fernandez MC, Jackson J, Hawkes J, Goldman WJ, Pramuk K, Reyes H, Sablan B, Sonobe T, Bo X (2003) Multinational study of major breast milk carotenoids of healthy mothers. Eur J Nutr 42:133-141

3. Castenmiller JJM, West CE (1998) Bioavailability and bioconversion of carotenoids. Annu Rev Nutr 18:19-38
4. Fawzi WW, Rifas-Shiman SL, Rich-Edwards JW, Willett WC, Gillman MW (2004) Calibration of a semi-quantitative food frequency questionnaire in early pregnancy. Ann Epidemiol 14:754-762

5. Fewtrell M, Lucas P, Collier S, Lucas A (2001) Randomized study comparing the efficacy of a novel manual breast pump with a mini-electric breast pump in mothers of term infants. J Hum Lact 17:126-131

6. Giuliano AR, Neilson EM, Yap H-H, Baier M, Canfield LM (1994) Quantitation of an inter/intra-individual variability in major caroteniods of mature human milk. J Nutr Biochem 5:551556

7. Goni I, Serrano J, Calixto-Saura F (2006) Bioaccessibility of $\beta$-carotene, lutein, and lycopene from fruits and vegetables. J Agric Food Chem 54:5382-5387

8. Hammond BR, Johnson EJ, Russell RM, Krinsky NI, Yeum K-J, Edwards RB, Snodderly DM (1997) Dietary modification of human macular pigment density. Invest Ophthalmol Vis Sci 38:1795-1801

9. Handelman GJ, Drarz EA, Reay CC, van Kuijk FJGM (1988) Carotenoids in the human macula and whole retina. Invest Ophthalmol Vis Sci 29:850-855

10. Handelman GJ, Nightingale ZD, Lichtenstein AH, Schaefer EJ, Blumberg JB (1999) Lutein and zeaxanthin concentrations in plasma after dietary supplementation with egg yolk. Am J Clin Nutr 70:247-251

11. HHS/USDA (2005) Dietary guidelines for Americans, 6th edn. US Government Printing Office, Washington, DC. www. healthierus.gov/dietaryguidelines. Accessed 13 March 2009

12. Jewell VC, Mayes CBD, Tubman TRJ, Northrop-Clewes CA, Thurnham DI (2004) A comparison of lutein and zeaxanthin concentrations in formula and human milk samples from Northern Ireland mothers. Eur J Clin Nutr 58:90-97

13. Johnson EJ, Hammond BR, Yeum K-J, Qin J, Wang XD, Castaneda C, Snodderly DM, Russell RM (2000) Relation among serum and tissue concentrations of lutein and zeaxanthin and macular pigment density. Am J Clin Nutr 71:1555-1562

14. Johnson L, Norkus E, Abbasi S, Gerdes JS, Bhutani VK (1994) Contribution of beta caroteine (BC) enriched formulae to individual and total serum carotenoids in term infants. In: Abstracts and program outline of the meeting of the American Pediatric Society and the Society for Pediatric Research. Seattle, Washington. 2-5 May 1994 (abstract 1869)

15. Kostic D, White WS, Olson JA (1995) Intestinal absorption, serum clearance, and interactions between lutein and $\beta$-carotene when administered to human adults in separate or combined oral doses. Am J Clin Nutr 62:604-610

16. Landrum JT, Bone RA (2001) Lutein, zeaxanthin, and the macular pigment. Arch Biochem Biophys 385:28-40

17. Lucas A, Gibbs JAH, RjL Lyster, Baum JD (1978) Creamatocrit: simple clinical technique for estimating fat concentration and energy value of human milk. Br Med J 1:1018-1020

18. Mares JA, LaRowe TL, Snodderly DM, Moeller SM, Gruber MJ, Klein ML, Wooten BR, Johnson EJ, Chappell RJ, For the CAREDS Macular Pigment Study Group and Investigators (2006) Predictors of optical density of lutein and zeaxanthin in retinas of older women in the carotenoids in age-related eye disease study, an ancillary study of the Women's Health Initiative. Am J Clin Nutr 84:1107-1122

19. Nantz MP, Rowe CA, Nieves C, Percival SS (2006) Immunity and antioxidant capacity in humans is enhanced by consumption of a dried, encapsulated fruit and vegetable juice concentrate. J Nutr 136:2606-2610

20. Riso P, Brusamolino A, Ciappellano S, Porrini M (2003) Comparison of lutein bioavailability from vegetables and supplement. Int J Vitam Nutr Res 73:201-205 
21. Roodenburg AJC, Leenen R, van het Hof KH, Weststrate JA, Tijburg LBM (2000) Amount of fat in the diet effects bioavailability of lutein esters but not of $\alpha$-carotene, $\beta$-carotene, and vitamin E in humans. Am J Clin Nutr 71:1187-1193

22. SanGiovanni JP, Chew EY, Clemons TE, Ferris FL 3rd, Gensler G, Lindblad AS, Milton RC, Seddon JM, Sperduto RD, Age-Related Eye Disease Study Research Group (2007) The relationship of dietary carotenoid and vitamin A, E, and C intake with age-related macular degeneration in a case-control study: AREDS Report No. 22. Arch Ophthalmol 125:12251232

23. Schweigert FJ, Bath K, Chen F, Buscher U, Dudenhausen JW (2004) Effect of the stage of lactation in humans on carotenoid levels in milk, blood plasma, and plasma lipoprotein fractions. Eur J Nutr 43:39-44

24. Seddon JM, Ajani UA, Sperduto RD, Blair N, Burton TC, Farber MD, Gragoudas ES, Haller J, Miller DT (1994) Dietary carotenoids, vitamins $\mathrm{A}, \mathrm{C}$, and $\mathrm{E}$, and advanced age-related macular degeneration. JAMA 272:1413-1420

25. Sommerburg O, Meissner K, Nelle M, Lenhartz H, Leichsenring M (2000) Carotenoid supply in breast-fed and formula-fed neonates. Eur J Pediatr 159:86-90

26. Tyssandier V, Cardinault N, Caris-Veyrat C, Amiot M-J, Grolier P, Bouteloup C, Azais-Braesco V, Borel P (2002) Vegetableborne lutein, lycopene, and $\beta$-carotene compete for incorporation into chylomicrons, with no adverse effect on the medium-term (3-week) plasma status of carotenoids in humans. Am J Clin Nutr 75:526-534

27. Van het Hof KH, West CE, Weststrate JA, Hautvast JGAJ (2000) Dietary factors that affect the bioavailability of carotenoids. J Nutr 130:503-506

28. Yeum K-J, Ferland G, Patry J, Russell RM (1998) Relationship of plasma carotenoids, retinol and tocopherols in mothers and newborn infants. J Am Coll Nutr 17:442-447 